\title{
Studies on some Javanese Anthocerotaceae. II.
}

\author{
BY \\ DOUGLAS HOUGHTON CAMPBELL. \\ Professor of Botany in Stanford University.
}

\section{With Plates IX and $\mathbf{X}$, and two Figures in the Text.}

$\mathrm{T}$ HE conditions in Western Java are especially favourable for the growth of Hepaticae, and among these is a large number of species of the Anthocerotaceae, of which many were collected. In a recent paper (Studies on some Javanese Anthocerotaceae, I, Ann. of Bot., vol. $x x i$, p. 467 ) two of these species, which were referred to a new genus, Megaceros, were described. The present paper is concerned with the species of Dendroceros and Notothylas, collected at the same time.

The species of Dendroceros are all tropical, and the first account of the development of these we owe to the researches of Leitgeb. ${ }^{1}$ Leitgeb studied several species of Dendroceros, and although he had only herbarium material to work with, he succeeded in making out the most important points of structure in the reproductive organs and embryo. The writer collected in Jamaica two species, D. Breutelii, N. ab E., and $D$. crispus ?, and was able to add a number of details which the insufficiency of his material prevented Leitgeb from noting. ${ }^{2}$

But one species of Dendroceros, D. javanicus, N. ab E., has been hitherto recorded from Java, ${ }^{3}$ but during the writer's stay in the island two very distinct species were collected, one at Tjibodas, the other at Lebak Saat on Mount Gedeh. Search was made for Dendroceros in the neighbourhood of Buitenzorg, but without success. As the species collected at Tjibodas was very inconspicuous and difficult to find, it is quite likely that the same or some similar species may occur at the lower level.

The original description of $D$. javanicus was not available, and for the present it must remain uncertain which (if either) of the species here described is the true $D$. javanicus. At Tjibodas, on the trunks of two or

1 Untersuchungen über die Lebermoose, iv, 1879 .

2 Campbell, On the Structure and Development of Dendroceros, Nees, Journ. Lin. Soc. London, xxxiii, p. 467,1898 .

Schiffner, Conspectus Hepaticarum Archipelagi Indici, Batavia, I 898.

[Annals of Botany, Vol. XXII. No. LXXXV. January, I908.] 
three trees near the edge of the forest, there was found growing a small species (Pl. IX, Fig. 4), which was assumed to be D. javanicus. Although careful search was made in various localities, no other specimens were found. A second, much larger species (Fig. I) was subsequently met with nearer the summit of Mount Gedeh. This was only found once, but was growing abundantly on the twigs of an undetermined shrub, and was quite conspicuous, while the other species growing among the mosses and liverworts on the bark of trees was very hard to find. The large species was growing at an elevation of 2,200 metres, which was rather unexpected, as Dendroceros usually prefers the warmer regions nearer sea-level.

The determination of the two species must be left until a comparison can be made with authentic specimens of $D$. javanicus. We shall simply refer to them here as species $A$, the large form from the higher station, and species $B$, the smaller form from Tjibodas. The former species is very much larger than the other (see Pl. IX, Figs. I and 4), and in many respects seems to agree with the plant which Leitgeb studied under the name D. javanicus. ${ }^{1}$ The magnification of Leitgeb's figures is not indicated, and it is impossible therefore to judge of the size of the plant studied by him. The thallus of form A (Fig. I) is about $3 \mathrm{~cm}$. in length, and more or less regularly pinnately branched. The midrib, as in all species of Dendroceros, is sharply defined, and the wings of the thallus consist of a thin lamina composed of but a single layer of cells. This lamina in the species in question is very much lobed and folded, so that it closely resembles such a liverwort as Fossombronia, the lobes of the lamina simulating leaves. In this respect it resembles Leitgeb's figure of $D$. javanicus, but the margin is even more irregular than in his figure. It also resembles the West Indian D. crispus, but is very much larger than any specimens of that species collected by the writer in Jamaica, and the margin of the thallus is very much more lobed and folded. The cells of the lamina are destitute of the large lacunae which are very conspicuous in the Tjibodas plant (Fig. 6), and in this respect it differs from Leitgeb's plant, which is described as having large lacunae in the lamina. The cells of the lamina show the collenchymalike thickenings at the angles that Leitgeb describes in Dendroceros Breutelii. The midrib is very massive, and contains large intercellular spaces, but these are not air-chambers, as Leitgeb states. He compares them to the air-chamber of the Marchantiaceae, but they are filled with mucilage, as they are in other Anthocerotaceae where such spaces are present. Leitgeb was probably misled by having to deal with dried material, where the drying up of the mucilage or its colourless character may have made him overlook the contents of these spaces. In stained microtome sections it is very evident that these intercellular spaces are not air-chambers. 
The antheridia of this species, which are very large, occur upon short lateral branches (Fig. $2 \sigma^{\top}$ ), and in this respect also the plant resembles Leitgeb's figures and description of $D$. javanicus.

The sporogonium is not very long, being only about $\mathrm{I} \mathrm{cm}$. in length, but is relatively stout, and opens along one suture (Fig. 3). The delicate columella may be seen projecting from the opening. The involucre is about half the length of the sporogonium.

The second species was found at Tjibodas, but only in a very limited area. As already stated, it was growing among mosses and liverworts upon the trunks of a few trees near the edge of the forest adjoining the garden. Although repeated search was made at other places, no more specimens were found. It is an excessively delicate little plant, and hard to recognize except when in fruit. It is only about one-third the size of the other species, and the thallus is dichotomously branched (Fig. 4). The wings of the thallus are very little folded or lobed, and the plant looks almost like a Metzgeria, and is not much larger than the common species of that genus. The wings contain very conspicuous lacunae (Fig. 6), in which respect it differs strikingly from the species A, but agrees with Leitgeb's account of D. javanicus. There are no lacunae in the midrib.

The antheridia and archegonia are both upon the same shoots, and the antheridia are much smaller than in the species A. The sporogonia are very slender, but are longer than in species $A$. The involucre is long, and the dehiscence is along one suture as in the other species (Fig. 5).

\section{The Anatomy of the Thallus.}

The form of the apical cell and its segmentation agree entirely with those of the other species that have already been investigated. The form of the apical cell (see Figs. 8 and 9) is very much like that of Pellia epiphylla and that of the prothallium of most Ferns, and it differs from that of the other genera of Anthocerotaceae in its forming basal segments extending the whole depth of the thallus. The two species are alike in the form and segmentation of the apical cell, but the species $\mathrm{A}$ has a thicker midrib and develops the conspicuous intercellular species already referred to (Fig. 9, l). These spaces are quite absent from the species B.

As in most Anthocerotaceae, each cell of the thallus contains a single large chromatophore, in which is a very distinct pyrenoid (Fig. $7, p$ ). The nucleus, $n$, is small and not at all conspicuous, but it is readily demonstrated.

\section{The Reproductive Organs.}

The archegonia (Figs. 9 to I2) are not in any way different from those of the other species that have been examined, and closely resemble those of Anthoceros. The neck-cells are usually slightly broader than in 
Anthoceros, but this is not very marked. As in other Anthocerotaceae, the archegonium projects but slightly above the level of the thallus. There are from two to four cover-cells in the ripe archegonium (Fig. 13), and these are thrown off when the archegonium opens. The neck-canal-cells usually number five.

The antheridia (Figs. 14 to 22), as in other species of Dendroceros, are borne singly in the antheridial cavity. No attempt was made to follow out the early development, as there was no indication that this differed in any marked degree from that of the other species that had been studied. There is no doubt of the endogenous origin of the antheridium, and, as in all other described species of Dendroceros, the archegonium lies nearly horizontal in the antheridial chamber and develops an extremely long pedicel, which is coiled up in the cavity. Leitgeb supposes that at maturity the stalk straightens out and projects the archegonium above the surface of the thallus. This point, however, was not investigated. The body of the antheridium is oval, and very early in its history the single layer of peripheral cells is separated from the inner spermatogenic tissue. Cross-sections of the pedicel (Fig. I9, $p$ ) show it to be composed of two rows of cells in all the specimens examined in both species. This agrees with Leitgeb's account of the species studied by him, but in $D$. Breutelii there may be four rows in some cases. ${ }^{1}$

The spermatozoids are too small to make a study of the spermatogenesis satisfactory, and no attempt was made to trace the development of the spermatozoids. After the last mitosis the spermatocytes are in pairs, apparently not separated by a cellulose membrane (Fig. 18). This is much like what occurs in many Hepaticae. Presumably the cilia arise from a blepharoplast, but this point was not demonstrated. The mature antheridium is very large in the species A (Fig. I9), being about $350 \mu$ in diameter. This is more than twice the size Leitgeb gives for $D$. javanicus (loc. cit., p. 32). The antheridium in the second species is much smaller (Fig. 22).

\section{The EMbryo.}

Leitgeb describes the older embryos of Dendroceros, but did not obtain the earlier stages. The writer succeeded in obtaining younger stages of D. Breutelii (loc. cit.), but the first divisions were not seen, although it was conjectured that the first division was a longitudinal one, as in Anthoceros. This has proved to be also the case in the two species under consideration (Fig. 23), and it will be safe to assume that this is the rule in Dendroceros. The second walls are transverse and nearly median. This first transverse division probably determines the boundary between the foot and the capsule. The next divisions are vertical, but

\footnotetext{
1 Camplell, loc. cit., p. $47^{2}$.
} 
to judge from transverse sections of the young embryo they are somewhat variable in position. Fig. 2.5 shows three sections of a young embryo of six cells. In this case the upper region was divided into four cells, but they were not quite regularly disposed. The foot-region consisted at this stage of but two cells. Fig. 24 shows a nearly median longitudinal section of an 8-celled embryo of the larger species, A, and in this case also the octant walls do not all fall in the same plane. The foot-cells have already begun to grow out into the root-like extensions, which later are so conspicuous.

The differentiation of the columella (endothecium) is the same as in Anthoceros (Fig. 26), and the separation from the amphithecium of a single layer of archesporial tissue is also the same as in Anthoceros, except that, as was pointed out in D. Breutelii and D. crispus (Campbell, loc. cit.), the archesporial layer extends quite to the transverse wall that marks the upper limit of the foot. In this respect Dendroceros closely resembles Megaceros, which in some other respects is also more like Dendroceros than it is like Anthoceros. There are, moreover, further periclinal divisions in the apical part of the sporogenous layer which otherwise remains but one cell thick (Figs. 27, 28). This is, however, less marked than in Megaceros or Notothylas (see Text-figs. I and 2).

The columella in the two Javanese species was better developed than in those from the West Indies, this being especially the case in species A. In cross section (Fig. 29), instead of the sixteen cells usually found in $D$. Breutelii there were sometimes nearly twice as many. Leitgeb figures a similar large columella in D. cichoraceus.

As in D. Breutelii and the other species studied by L.eitgeb, the sporogenous layer, except above the apex of the columella, remains but one cell in thickness or very imperfectly duplicated in places. This is much like the smaller species of Anthoceros such as A.laevis. ${ }^{1}$ In the larger species, e.g. A. Pearsoni (Text-fig. 2, C), the doubling of the sporogenous layer is complete. In Megaceros, which in so many ways closely resembles Dendroceros, there are from three to four layers of cells when the celldivisions are completed (Text-fig. 2, B).

Fig. 29 shows a transverse section of the sporogonium of species $A$ some distance above its base. The large columella is surrounded by a single layer of archesporial cells, while the outer part of the sporophyte consists of from four to five layers of cells, which develop chlorophyll. The number of layers of cells in the wall may, in the larger species, become seven or eight. In no cases were stomata observed, and this agrees with all the other species of Dendroceros as well as with Megaceros.

No rule could be made out as to the origin of the fertile and sterile cells of the archesporium. The spore-mother-cells can soon be

\footnotetext{
1 See Davis, the Spore Mother Cell of Anthoceros, Bot. Gaz., xxviii, I 899 .
} 
recognized by their rounded form and greater diameter. The sterile cells remain narrow and are soon easily distinguishable from the rounded spore-mother-cells. The division of the latter was not followed, as there was no evidence that it was different from the other forms that have been studied. The two Javanese species do not differ much in the size of the ripe spores (Fig. 30), but the species A has both the columella and the outer tissue much more developed than the smaller one. In the latter there are seldom more than four layers of cells in the sporogoniumwall, while in the larger species there may be as many as eight. The superficial cells of the smaller species are longer and narrower than in the larger one, and in the latter they often project slightly.

After the division of the spore-mother-cell is completed, the spores remain together in tetrads until they are almost ready to be discharged from the sporogonium. While still together, a thin, finely papillate perinium is developed and the spores undergo repeated division, so that each one is a multicellular body of considerable size (Fig. 30). Both of the Javanese species agree in this respect, and this is known to be the case also in a number of others, e.g. D. crispus, D. cichoraceus. The cell-mass derived from the spores has a large amount of chlorophyll, and really germination begins inside the sporogonium, as it does in Pellia and Fegatella.

The elaters, as in the other species of Dendroceros, are multicellular, and are to be considered as fragments of the net of sterile cells which incloses the spores. There is a broad spiral band of a yellowish brown colour, which is scarcely interrupted by the division walls between the cells of the elater (Fig. $3 \mathrm{I}$ ).

\section{Notothylas javanicus.}

In the garden at Buitenzorg, and at other places in the vicinity, a species of Notothylas, presumably $N$. javanicus, was not at all uncommon. Material of this species was collected in order to compare it with the common American species, $N$. orbicularis, which is the only species that has been completely investigated. ${ }^{1}$ The statement of Leitgeb, that the columella in Notothylas is not infrequently quite absent or may be of secondary origin, was not confirmed by Mottier in the case of $N$. orbicularis. $N$. javanicus was examined carefully with reference to the same point, and the conclusions reached agree essentially with those of Mottier with reference to $N$. orbicularis. $N$. javanicus closely resembles in general appearance $N$. orbicularis. The thallus is usually nearly orbicular, due to a repeated and rapid dichotomy. It is somewhat yellowish-green in colour, and the sporogonia project but little from the involucre. Where

1 Mottier, Contributions to the Life History of Notothylas, Ann. of Bot., viii, 1894; Campbell, Development of the Mosses and Ferns, First Ed., 1895. 
the sporogonia are abundant the short, nearly horizontal capsules occur quite thickly set round the margin of the thallus. Quite often dwarf sporogonia are met with, resembling those described in other species, and like these are probably due to imperfect nutrition.

Sections of the thallus of $N$. javanicus show it to be quite solid, and no trace of the mucilage-cavities which are conspicuous in $N$. orbicularis can be found. The apical growth (Pl. X, Figs. 32, 33) is exactly like that of Anthoceros and Megaceros, there being two sets of segments, dorsal and ventral, cut off from the large initial cells.

\section{The Reproductive Organs.}

The archegonia are similar in origin and development to those of Anthcceros, but they are somewhat broader in the early stages, and the number of neck-canal-cells is usually less. In all the specimens of $N$. javanicus that were examined there were but three neck-canal-cells (Figs. $3^{2}, 34$ ), and Mottier found this to be true in $N$. orbicularis, although the writer found as many as five in the latter species. The number of ripe archegonia that were examined in $N$. javanicus was not very large, and it is not impossible that in this species also there may exceptionally be more than three neck-canal-cells.

In some cases the neck-cells are cut off by a longitudinal wall after the first transverse cell of the young archegonium has been formed ( $\mathrm{Pl}$. X, Fig. 33). In such cases the neck-canal-cells are narrower than when this longitudinal wall is suppressed. An abnormal case was seen in which the egg-cell had divided into two by a longitudinal division wall after the cutting off of the ventral canal-cell (Fig. 34). There are usually two cap-cells present. Whether more than this may be formed in $N$. javanicus was not determined. The antheridia (Fig. 35) are formed usually four together in the antheridial cavity, and apparently do not differ in any important particular from those of $N$. orbicularis. ${ }^{1}$

\section{THE EMBRYo.}

Neither Leitgeb nor Mottier described the earliest stages of the embryo. The latter thinks that in $N$. orhicularis the first division-wall is transverse. This does not seem to be the case in $N$. javanicus to judge from the few young embryos that were examined. In one case a two-celled embryo was sectioned (Fig. 35). This was divided longitudinally exactly as in Anthoceros. The next youngest embryo seen (Fig. 37) was divided into three tiers by two transverse sets of walls, and in this case at least it was clear that the development of the columella and archesporium was confined to the uppermost segment of the embryo

${ }^{1}$ See Campbell, Mosses and Ferns, Second Ed., Fig. 80. 
as in Anthoceros. The small endothecium in this case was cut off by a periclinal wall. Fig. $3^{8}$ shows a median longitudinal section of an older embryo in which the archesporium is completely differentiated. It agrees entirely with $N$. orbicularis in this respect; and as Mottier showed, the archesporium is of amphithecial origin and formed in exactly the same way as in Anthoceros.

Cross-sections of embryos of about the same stage as that represented in Fig. $3^{6}$, show much the same appearance as similar sections in the other genera, except that the columella is much less developed. While in
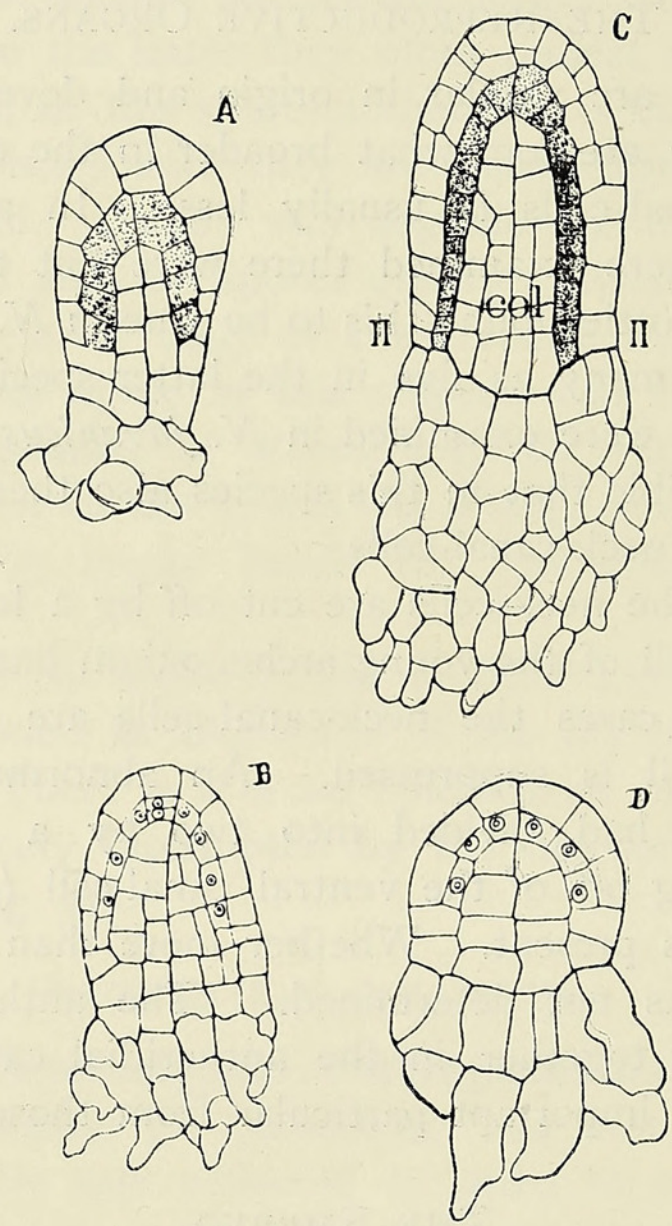

Text-fig. I. Median longitudinal sections of embryos of about the same age, showing the extent of the archesporium in the four genera of Anthocerotaceae. A. Notothylas orbicularis; B. Dendroceros Breutelii; C. Megaceros tjibodensis; D. Anthoceros Pearsoni.

the larger sporogonia (Fig. 44) the columella may show three cells in longitudinal section, most of the smaller ones showed but four cells in cross-section, and it is less developed than in $N$. orbicularis. In some specimens but three cells were seen in cross-section (Fig. 42). This would indicate that the columella-cells were entirely suppressed in one of the quadrants of the embryo, and presumably in this quadrant the endothecium would contribute to the sporogenous tissue. In no specimens that were examined, however, was the columella entirely absent, and 
it is doubtful whether this is ever the case, as Leitgeb supposed it to be. Except in microtome sections it would be quite impossible to recognize the slender columella obscured by the massive sporogenous tissue which surrounds it. The sporogonium becomes pear-shaped (Fig. 43), and the single layer of sporogenous tissue increases very much in thickness, becoming ultimately three or four cells thick (Fig. 44). Above the summit of the columella, which is not always very clearly defined in the upper region, the sporogenous tissue divides rapidly and forms a large mass (Fig. 43). The differentiation of the sporogenous and sterile cells of the archesporium is entirely similar to that of $N$. orbicularis. There is a pretty regular alternation of horizontal layers of fertile and sterile cells, the latter $(s p)$ very soon becoming recognizable on account of their larger size.

The foot in Notothylas is much smaller than in Dendroceros and
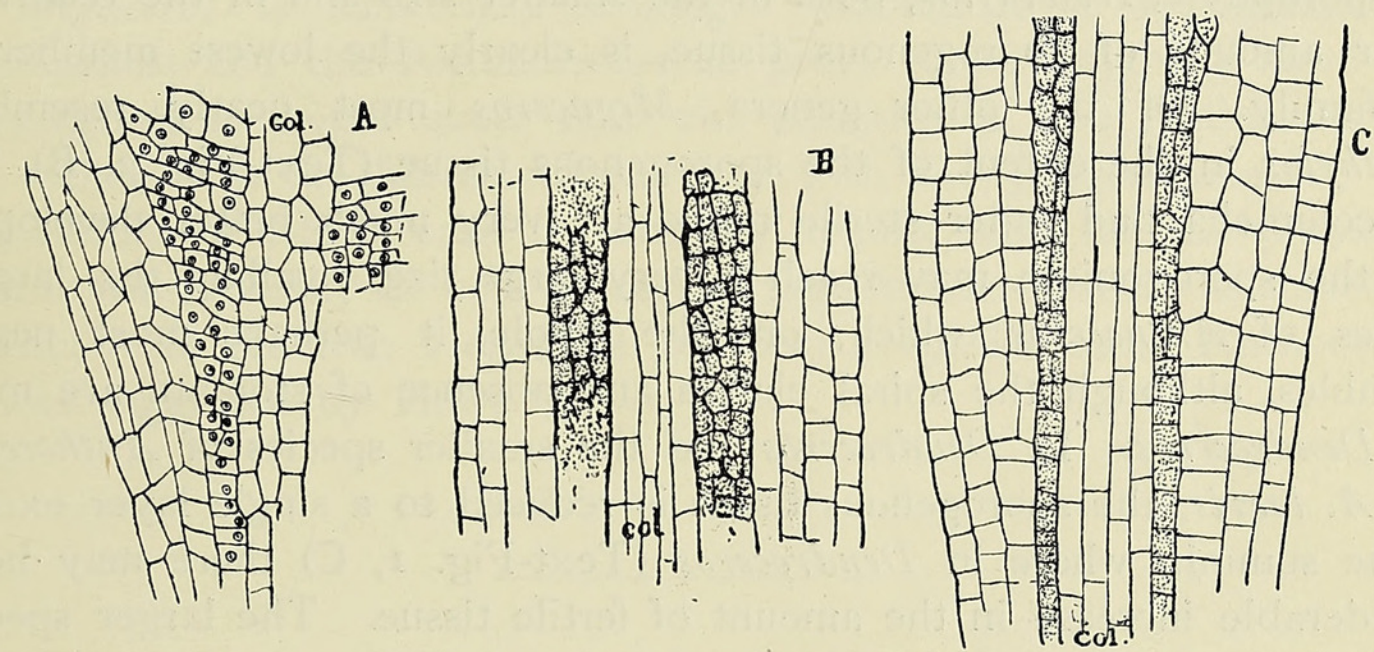

TEXT-FIG. 2. Median sections near the base of older sporophytes of Notothylas (A), Megaceros (B), and Anthoceros (C), showing the relative size of the archesporium in the three genera.

Anthoceros, corresponding to the smaller size of the sporophyte. The root-like outgrowths are, however, well developed and appear at an early stage in the growth of the embryo (see Figs. 38,39 ).

It is clear that in normal cases, at least, the sporogonium of $N$. javanicus develops in precisely the same way as that of $N$. orbicularis or the other Anthocerotaceae. There is no evidence of a secondary formation of the columella from potentially sporogenous tissue, as Leitgeb surmises is the case in some forms of $N$. fertilis. The great reduction of the columella in some of the stunted sporogonia makes it quite conceivable that this may be carried a stage further and that sporogonia might be formed without a columella; but no cases of this were seen, although a good many young sporogonia were sectioned, and there is no question that usually, at least, a columella is formed and that it always originates in the same way as that of the other Anthocerotaceae. 


\section{Affinities of the Anthocerotaceae.}

Notothylas is without doubt the simplest and probably the most primitive of the Anthocerotaceae. Of the other genera Anthoceros closely resembles Notothylas in the general character of the thallus and sexual organs. Megaceros is to some extent intermediate between Anthoceros and Dendroceros, resembling the former in the general structure of the thallus, but having the solitary antheridium characteristic of Dendroceros. Whether the single antheridium is a more primitive character than the group of antheridia found in Notothylas and most species of Anthoceros it is impossible to determine. The question is also open as to whether the type of thallus in Notothylas and Dendroceros is the more primitive. A comparison might be made with the type of thallus found in Pallavicinia and Aneura among the Jungermanniaceae. In regard to the sporophyte, Notothylas, both in the smaller size and in the relatively larger amount of sporogenous tissue, is clearly the lowest member of the family. Of the other genera, Megaceros most nearly resembles Notothylas in the extent of the sporogenous tissue (Text-Fig. 2, B), but the columella and outer sterile tissue are very much better developed, and the sporogonium may reach a very large size, rivalling the largest species of Anthoceros, which, on the whole, it perhaps most nearly resembles, although the spiral elaters and absence of stomata are more like Dendroceros. In Dendroceros and the smaller species of Anthoceros, e.g. A. laevis, the sporogenous tissue is reduced to a single layer except at the summit, where in Dendroceros (Text-Fig. I, C) there may be a considerable increase in the amount of fertile tissue. The larger species of Anthoceros, with their highly developed assimilative tissue and perfect stomata, may probably be considered as the highest existing form of this peculiar form of sporophyte.

The next question to be considered is the relation of the Anthocerotaceae to other forms. The peculiar solitary chromatophore characteristic of most of these is so closely similar to that of many green Algae that it is probable it is an inheritance from some algal ancestor. This peculiarity has been supposed to be universal among the Anthocerotaceae, but it has been recently shown that in the group of the genus Anthoceros, which the writer has proposed to separate as a special genus, Megaceros, there are normally several chromatophores in the inner cells of the thallus, and that these chromatophores are usually destitute of a pyrenoid and in all respects closely resemble the normal chromatophores of the higher plants.

Leitgeb has assumed a remote relationship of Notothylas with the Jungermanniales, and believed that he had found sporogonia of the former in which the sporogenous tissue arose from the endothecial tissue. 
As we have pointed out, this formation of the sporogenous tissue from the central part of the sporogonium has not been confirmed by the writer's study of $N$. javanicus, although the slight development of the columella in some of the small sporogonia indicates the possibility of a complete suppression of the columella in the poorly nourished sporogonia.

A comparison of the sporogonium of Notothylas is perhaps best made with Sphaerocarpus or even better with Cyathodium. ${ }^{1}$ The latter is especially interesting, as the foot of the sporogonium, unlike that of any other liverwort, produces root-like extensions like those of the typical Anthocerotaceae. It is also worthy of note that the Targionieae, and especially Cyathodium, are characterized by remarkably large chromatophores, those in $C$. foetidissimum being sometimes reduced to four in some of the assimilative cells. The writer has examined this point in specimens collected in Java, and the resemblance to the chromatophores of Megaceros is sufficiently striking. Should these resemblances in Cyathodium and the Anthocerotaceae prove to be anything more than coincidences it would show that the affinities of the Anthocerotaceae are rather with the Marchantiales than with the Jungermaniales. The relationship in either case is certainly remote, and for the present at least it will probably be best to regard the Anthocerotaceae as sufficiently distinct from the true Hepaticae to form a special class, Anthocerotes, as was suggested by Howe. ${ }^{2}$

\section{EXPLANATION OF PLATES IX AND $\mathrm{X}$.}

Illustrating Professor Campbell's Studies on Anthocerotaceae, II.

PLATE IX.

Fig. 1. Dendroceros sp. (A). Thallus. $\times 3$.

Fig. 2. Apex of a shoot with antheridial branch, $\sigma^{T} . \times 3$. sp, young sporophytes.

Fig. 3. Two ripe sporogonia of the same. $\times 3$. col, columella ; in, involucre.

Fig. 4. Plant of Dendroceros sp. (B) with two sporogonia, $s p$. $\times 3$.

Fig. 5. A ripe sporogonium of the same. $\times 3$.

Fig. 6. Cells of the wings of the thallus of $B$, showing the large lacunae. $\times$ IIo.

Fig. 7. A single cell showing the chromatophore with the included pyrenoid, $p . \times 280$. $n$, nucleus.

Fig. 8. Apical region of the thallus of $\mathrm{B}$, longitudinal section. $\times 280$.

Fig. 9. A similar section of $\mathrm{A}$; $q$, archegonia ; $l$, mucilage cavities.

Fig. 10. Young archegonium of A. $\times 480$.

Fig. 11. Young archegonium of B. $\times 480$.

Fig. 1 2. Open archegonium of B. $\times 280$.

1 Lang, On the Morphology of Cyathodium, Ann. of Bot., xix, p. 4II, 1905 .

${ }^{3}$ Mem. Torrey Botanical Club, vii, 1899 . 


\section{IO2 Campbell.--Studies on some Faranese Anthocerotaceae. II.}

$\times 280$.

Fig. 13. Transverse section of the apex of the archegonium, showing three cover-cells, $d$.

Fig. I4. Longitudinal section of an antheridial shoot of A. $\times 25 . n$, Nostoc colony ; $M$, mucilage cavities; $\sigma^{\top}$, antheridia.

Figs. $\mathrm{I}^{-1} 7$. Development of the antheridium in A. $\times 280$.

Fig. 18. Spermatogenic cells after the last division. $x$ about 600 .

Fig. 19. Ripe antheridium of A. $\times$ I IO. $p$, section of the pedicel.

Fig. 20. Young antheridium of B. $\times 280$.

Fig. 2I. An older antheridium of B. $\times 280$.

Fig. 22. Ripe antheridium of B. $\times$ I 10.

Fig. 23. Two longitudinal sections of a two-celled embryo of A. $\times 280$.

Fig. 24. An 8-celled embryo of A. $\times 280$. $c$, base.

Fig. 25. Three transverse sections of a 6-celled embryo of $B$. $\times$ about 600 . a apex;

Fig. 26. Two longitudinal sections of a young embryo of B. $\times 280$. The separation of endothecium and amphithecium is complete.

Fig. 27. Median longitudinal section of an older embryo of $A . \times 280$. The archesporial tissue has the nuclei shown.

Fig. 28. Longitudinal section of the young sporophyte of A, showing the extent of the archesporial tissue, $s p$; the columella, col; $f$, the foot. $\times 65$.

Fig. 29. Transverse section near the base of the young sporophyte of $\mathrm{A}$; the archesporial cells have the nuclei shown. $\times 280$.

Fig. 30. Section of ripe spore tetrad of A, showing the cell-divisions in the spores. $\times 280$.

Fig. 31. Fragment of a ripe elater. $\times 280$.

\section{PLATE $X$.}

All figures refer to Notothylas javanicus, N. ab E.

Fig. $3^{2}$. Longitudinal section of the apex of the thallus with a nearly mature archegonium, $q$; $x$, apical cell. $\times 280$.

Fig. 33. A similar section, with young archegonium. $\times 600$.

Fig. 34. An abnormal archegonium with the egg-cell divided into two. $\times 480$. $v$, ventral canal-cell.

Fig. 3 . Nearly mature antheridium. $\times 280$.

Fig. 36. Two-celled embryo. $\times 4^{80}$.

Fig. 37. An older embryo. $\times 480$. $I I$, first transverse wall; $e n$, one of the primary endothecium-cells.

Fig. 38. Median longitudinal section of an older embryo; the archesporial cells show the nuclei. $\times 280$.

Figs. 39-4 $\mathrm{r}$. Five transverse sections of an older embryo. $\times 280 . a, b$, through the foot; $c, d$, nearly median sections ; $c$, above the summit of the columella.

Fig. 42. Transverse section of an older embryo, showing but three rows of cells in the columella. $\times 280$.

Fig. 43. Median longitudinal section of young sporophyte. $\times 280$. The archesporium is shaded,

Fig. 44. Median longitudinal section near the base of a large sporophyte; col, columella; $s p$, fertile; $e l$, sterile cells of the archesporium. $\times 280$. 
Annals of Botany.
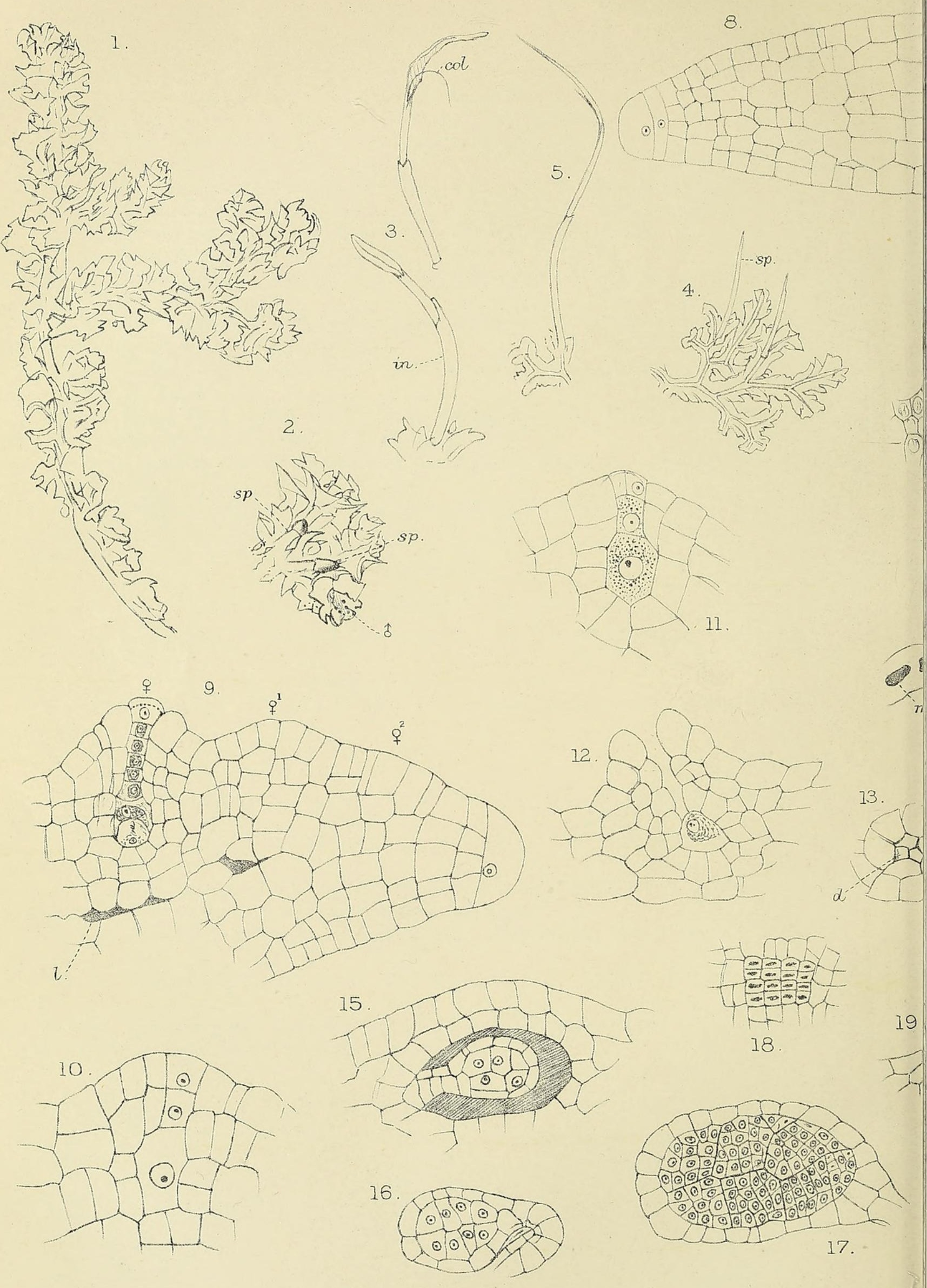

D.H.Campbell del 
Annals of Botany.
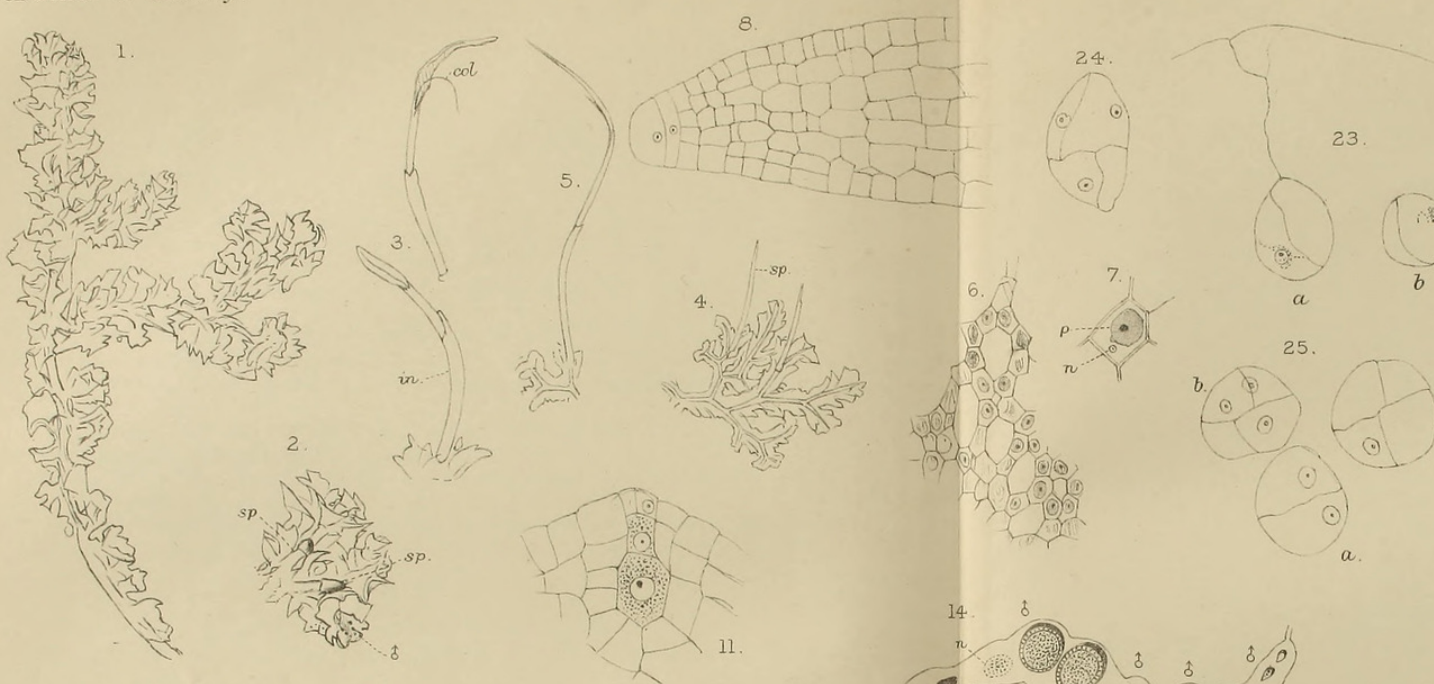

Vol. XXII PLIX
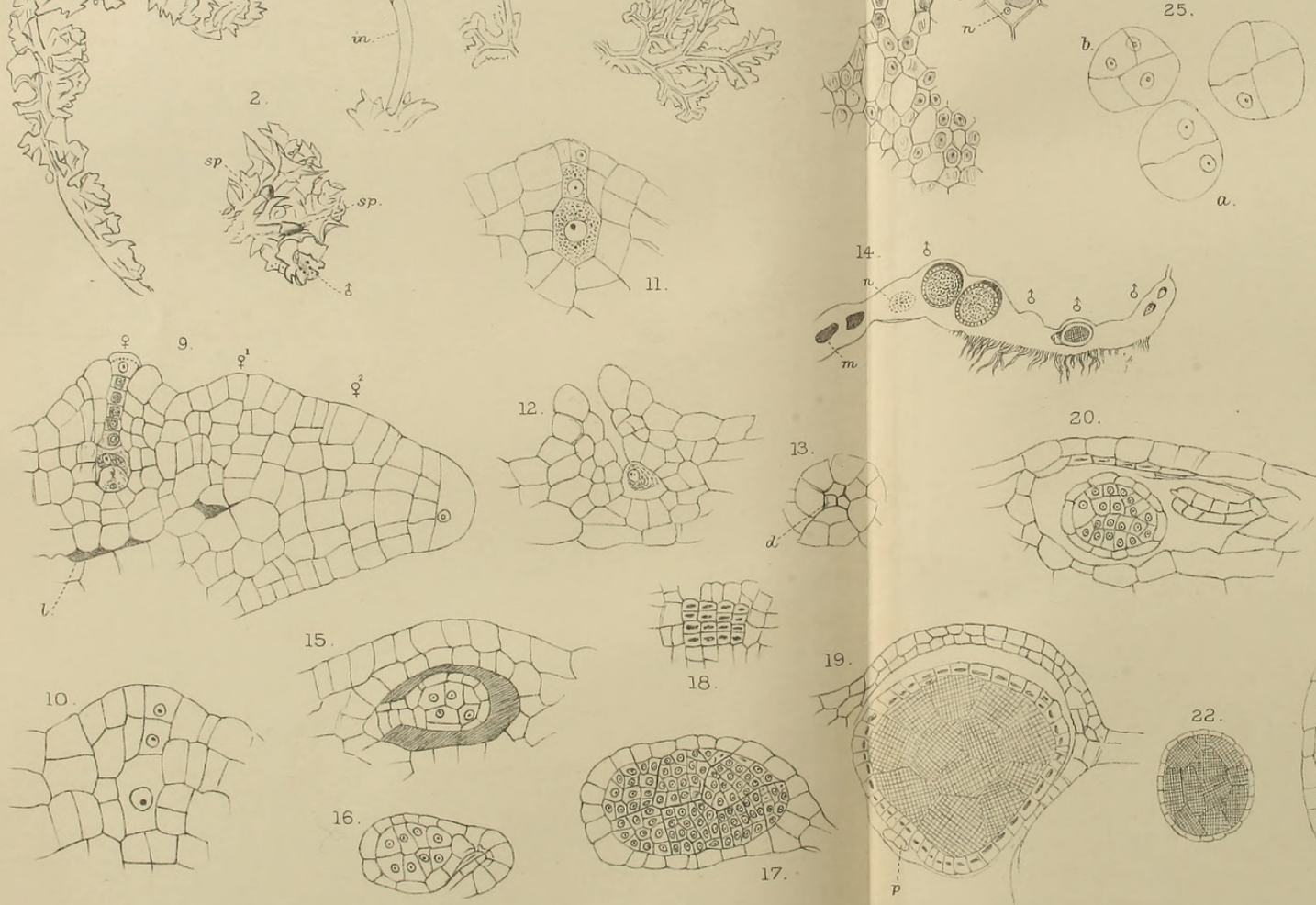

D H. Campbell del.
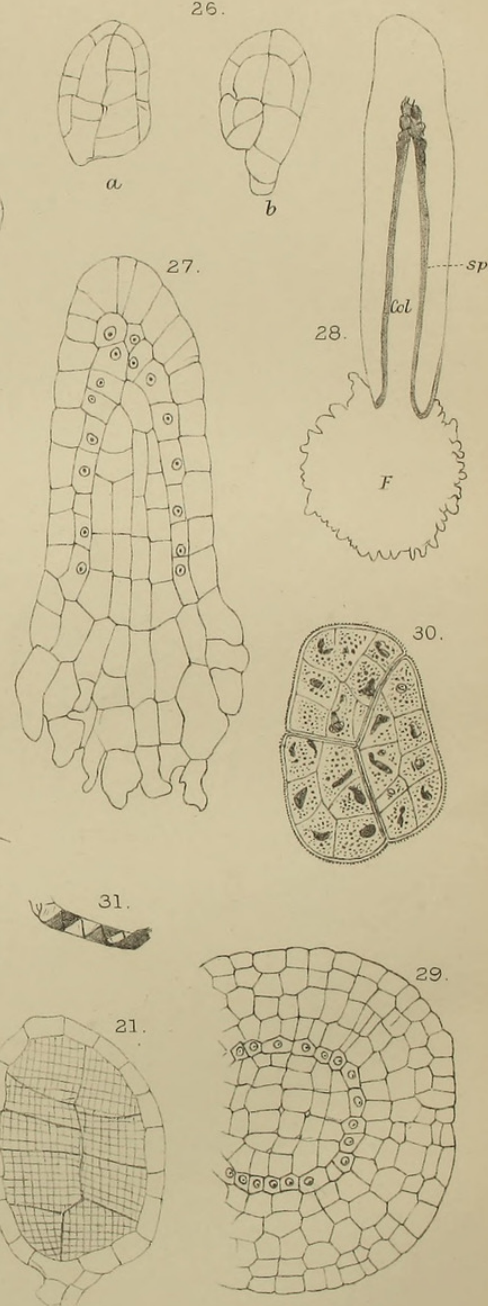

Huch lith et imp 


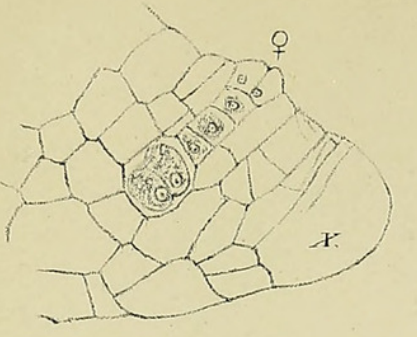

32

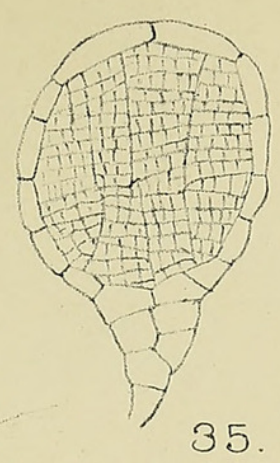

35

33.

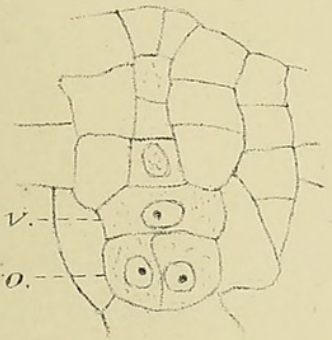

34.

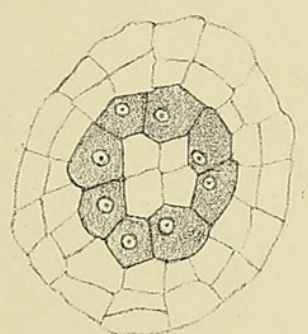

d
40 $a$ r:

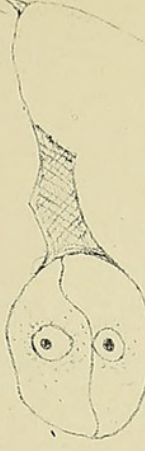

36.

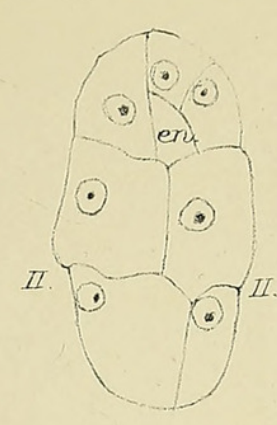

37.

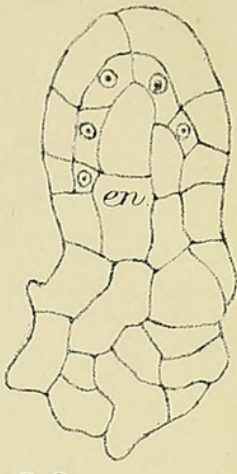

38.

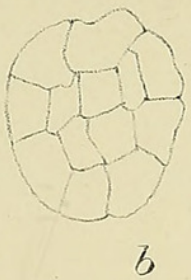

39.
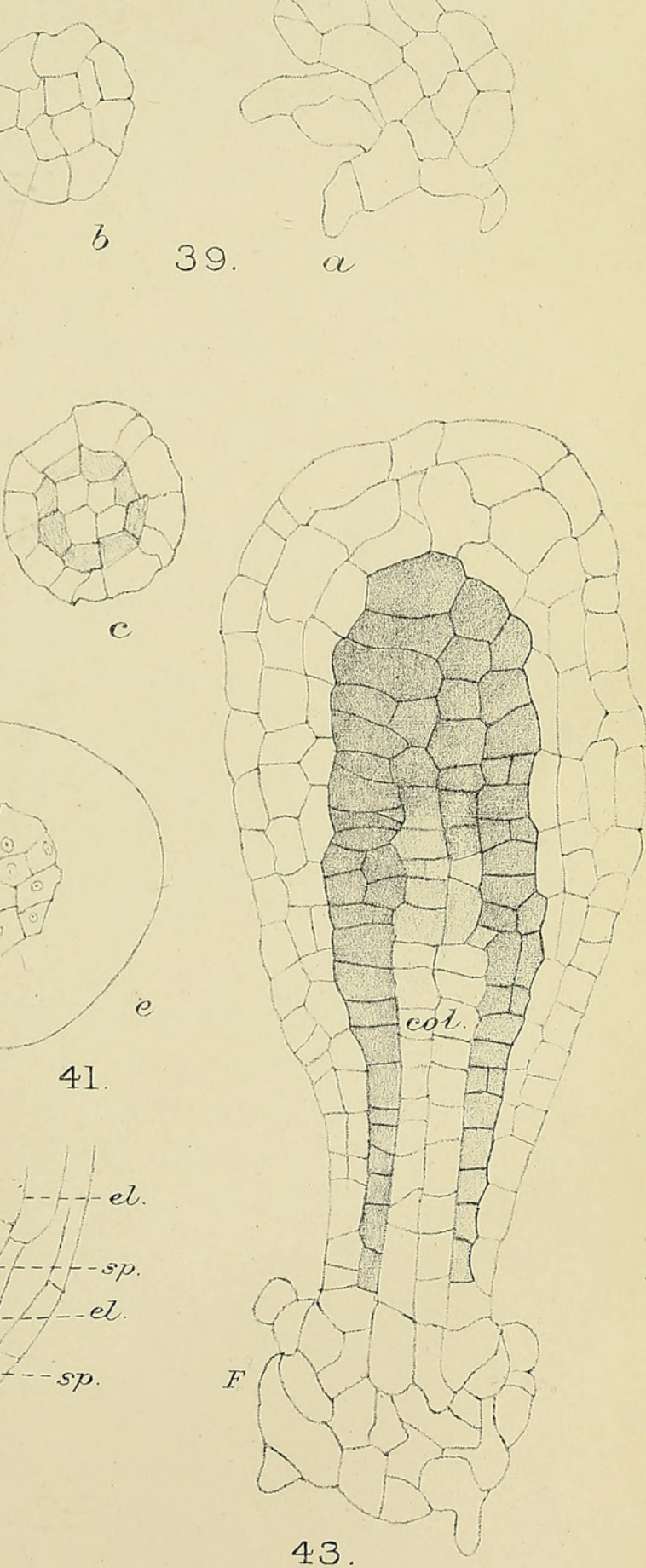

44.

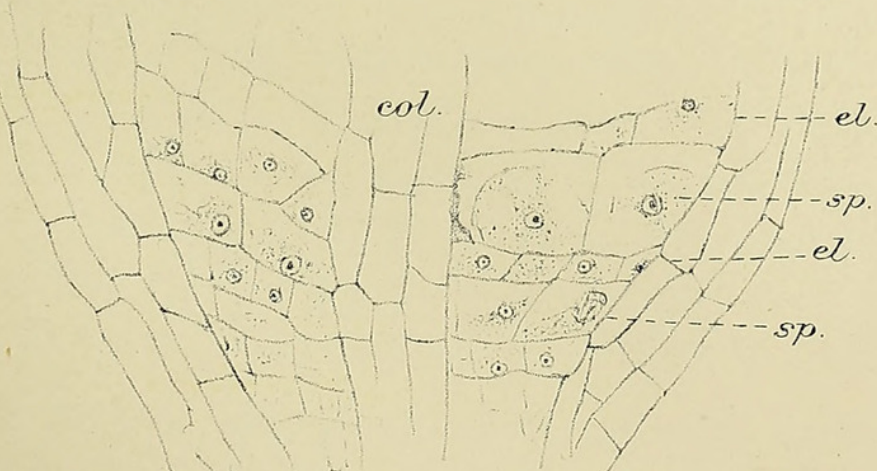

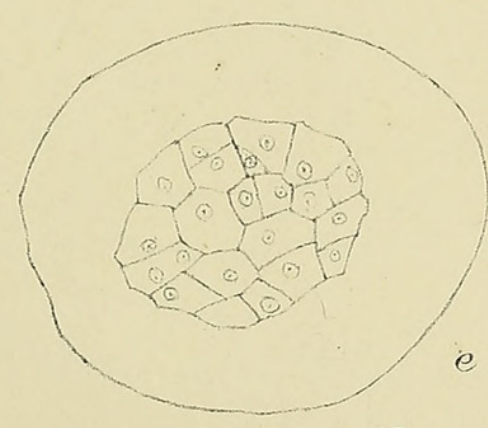

41 


\section{$2 \mathrm{BHL}$ Biodiversity Heritage Library}

Campbell, Douglas Houghton. 1908. "Studies on some Javanese Anthocerotaceae. II." Annals of botany 22, 91-102. https://doi.org/10.1093/oxfordjournals.aob.a089164.

View This Item Online: https://www.biodiversitylibrary.org/item/232525

DOI: https://doi.org/10.1093/oxfordjournals.aob.a089164

Permalink: https://www.biodiversitylibrary.org/partpdf/318895

\section{Holding Institution}

Smithsonian Libraries

\section{Sponsored by}

Biodiversity Heritage Library

\section{Copyright \& Reuse}

Copyright Status: Not in copyright. The BHL knows of no copyright restrictions on this item.

This document was created from content at the Biodiversity Heritage Library, the world's largest open access digital library for biodiversity literature and archives. Visit BHL at https://www.biodiversitylibrary.org. 